\title{
ОРГАНІЗАЦИЙНО-ПЕДАГОГІЧНІ ПЕРЕДУМОВИ СТАНОВЛЕННЯ І РОЗВИТКУ ЛЬВІВСЬКОГО УНІВЕРСИТЕТУ
}

У статті проаналізовані організаџійно-педагогічні передумови становлення та розвитку Львівського (1661-1939 роки) університету. Мета дослідження - обгрунтування процесу становлення та розвитку класичної університетської освіти в Західній Украӥні у другій половині XVII - на початку XX століття.

Для досягнення мети поставлені такі завдання:

1) проаналізувати стан розроблення проблеми становлення і розвитку класичної університетської освіти на західноукраӥнських землях (друга половина XVII - початок XX століття) у науково-педагогічній літературі;

2) виявити передумови становлення і розвитку класичної університетської освіти в Західній Україні (друга половина XVII - початок XX століття);

3) розкрити зміст освітнього прочесу Львівського університету.

У роботі використано такі методи дослідження: пошуково-бібліографічний (з метою здійснення добору, систематизачії, аналізу і класифікації інформаційних джерел), хронологічно-системний (використано для наукового обтрунтування процесу становлення та розвитку класичної університетської освіти), проблемно-генетичний (проведений з метою актуалізації досвіду діяльності класичних університетів Західної Украӥни), ретроспективний логіко-системний аналіз (спрямований на виявлення провідних ідей діяльності особистостей, які вплинули на становлення та розвиток класичних університетів Західної Украӥни).

Наукова новизна одержаних результатів роботи полягає в тому, щзо в ній вперше виявлено передумови становлення та розвитку університетської освіти в Західній Україні другої половини XVII - початку XX століття, розкрито зміст освітнього прочесу Львівського університету.

Досягнення університетської освіти в Західній Україні другої половини ХVII - початку ХХ століття дозволяють стверджувати, що система вітчизняної класичної університетської освіти має глибоке історичне коріння, трунтовну наукову основу й непересічну національну традицію.

Ключові слова: університетська освіта, Львівський університет, братства, просвітництво.

Kseniia KUGAI,
orcid.org/0000-0001-9838-904X
Senior Teacherat Foreign Languages Department
of Kyiv National University of Technologies and Design
(Kyiv,Ukraine) sketch_k2008@ukr.net

\section{ORGANIZATIONAL AND PEDAGOGICAL PRECONDITIONS FOR THE FORMATION AND DEVELOPMENT OF LVIV UNIVERSITY}

The article deals with organizational and pedagogical preconditions for the formation and development of Lviv (1661-1939) university. The purpose of the study is to establish scientific rationale for the process of formation and development of classical university education in Western Ukraine in the second half of XVII - early XX centuries.

To achieve this goal, the following tasks are set:

1) to analyze the problem of formation and development of classical university education in Western Ukraine (second half of XVII - beginning of XX centuries) in scientific and pedagogical literature;

2) to identify the preconditions for the formation and development of classical university education in Western Ukraine;

3) to reveal the content of educational process at Lviv University.

Such research methods are used: searching and bibliographic (with the purpose of information sources selection, systematization, analysis and classification); chronologically systemic (used for scientific rationale for the process of classical university education formation and development); problem-genetic (conducted to actualize the experience of classical universities in Western Ukraine) and retrospective logical-systemic analysis (aimed at identifying the leading ideas of the activities of individuals who influenced the formation and development of classical universities in Western Ukraine).

The scientific novelty of the results obtained is that it first revealed the preconditions for the formation and development of university education in Western Ukraine in the second half of XVII-early XX centuries; the content of the educational process of Lviv university was revealed (the studies were conducted according to the programmes of Jesuit schools, 
but gradually the content of the most faculties programmes became secular, the Russian Institute was opened, where Ukrainian children studied.

Achievements of university education in Western Ukraine in the second half of XVII - early XX century allow us to claim that national classical university education system has deep historical roots, sound scientific basis and unique national tradition.

Key words: university education, Lviv University, brotherhoods, enlightenment.

Постановка проблеми. Історія розвитку вищої школи є об'єктом історико-педагогічних досліджень. Навіть більше, ці дослідження необхідні для створення нової моделі вищої освіти в Україні в новому столітті.

Вивчення педагогічної спадщини минулого 3 iii досягненнями й упущеннями дає можливість ученим узагальнити реальну картину розвитку вітчизняної педагогічної думки як цілісного багатогранного явища, виокремити національні концептуальні дискусії та проаналізувати їх відповідно до сучасних вимог.

Відсутність історико-педагогічних праць, які $б$ цілісно відображали розвиток Львівського університету другої половині XVII - початку XX ст., зумовила вибір теми дослідження.

Аналіз досліджень. Історію становлення і розвитку університетської освіти, зокрема й на західноукраїнських землях, у різні періоди частково досліджували А. Аврус, В. Ботушанський, А. Горбань, 3. Зайцева, М. Зубрицька, Н. Дем'яненко, I. Курляк, Н. Ладижець та ін.

Діяльність братств та їхній внесок у становлення та розвиток вищої освіти досліджували такі науковці, як: Б. Год, Л. Коба, Я. Ісаєвич, К. Харлампович та інші.

Серед спеціальних історичних досліджень треба назвати працю С. Сірополка «Історія освіти в Україні» (2001р.), у якій автор приділяє увагу становленню та розвитку класичних університетів на території України, від виникнення перших класичних вищих навчальних закладів у XVI ст. i до радянської перебудови університетської освіти в 1930-х pр., а також розкриває особливості їхньої діяльності.

Мета статті - обгрунтування процесу становлення та розвитку класичної університетської освіти в Західній Україні у другій половині XVII - на початку XX ст.

$\mathrm{У}$ роботі використано такі методи дослідження, як: пошуково-бібліографічний (з метою здійснення добору, систематизації, аналізу і класифікації інформаційних джерел), хронологічносистемний (для наукового обгрунтування процесу становлення та розвитку класичної університетської освіти), проблемно-генетичний (з метою актуалізації досвіду діяльності класичних уні- верситетів Західної України) і ретроспективний логіко-системний аналіз (спрямований на виявлення провідних ідей діяльності особистостей, які вплинули на становлення та розвиток класичних університетів Західної України).

Наукова новизна одержаних результатів роботи полягає в тому, що вперше виявлено передумови становлення та розвитку університетської освіти в Західній Україні другої половини XVII - початку XX ст. (перебування українських земель у складі різних держав, насадження католицизму на території українського православ'я, викладання в навчальних закладах переважно латинською, німецькою, польською, румунською мовами й ін.); розкрито зміст освітнього процесу Львівського (1661-1939 рр.) університету (в університеті навчання проходило за програмами єзуїтських шкіл, але поступово зміст програм більшості факультетів набув світського характеру, при університеті було відкрито Руський інститут, покликаний готувати учителів для гімназій, де навчалися українські діти).

Виклад основного матеріалу. Виникнення й становлення вищої університетської освіти в Україні, як суспільно-історичний процес, тісно пов'язане з подіями історичного розвитку держави і співвідноситься із процесом становлення університетської освіти в інших країнах світу. Передумовами становлення університетської класичної освіти в Україні були розвиток діяльності дошкільної, шкільної, середньої освіти, діяльність братств (Кугай, 2019: 4). На особливу увагу заслуговує становлення й розвиток гуманітарної університетської освіти, що заклала основу вітчизняної вищої освіти й слугувала джерелом провідних ідей упродовж кількох століть іiі розвитку.

Початок XVII ст. прийнято називати першим українським відродженням, оскільки цей час характеризується помітним розвитком освіти, друкарень і книжкової продукції.

Велику роль у поширенні освіти (спочатку шкіл, а згодом вищої освіти) відіграли братства, які активно діяли вже на початку XVII ст. Це були національно-релігійні громадські організації українських і білоруських православних міщан; організації міського населення, передусім ремісників і купців, які об'єднувалися 3 метою 
боротьби проти ополячення й окатоличення українського населення (Артемова, 2006). Братства унікальний феномен у національній історії українського народу щодо ролі, яку вони відіграли в консолідації народності на ідеологічних засадах православ'я та завдяки роботі серед усіх верств населення. Архівні джерела характеризують братства як особливі спільноти при церквах, які надали велику допомогу в боротьбі за православ'я. Центральною основою цих спільнот стають храми, монастирі, каплиці (Ефименко, 1983).

Братства були досить поширеними в Європі. В Україні братства мали на меті просвітницьку діяльність. Конфлікт католицизму із православ'ям на початку XVII ст. став підгрунтям не лише для релігійної полеміки, а й для створення національної школи. Саме братські школи відіграли вирішальну роль у формуванні й утвердженні національної системи освіти в Україні.

Своїм найважливішим завданням братства вважали поширення освіти серед українського населення, захист української нації, а водночас і оборону православ'я перед натиском католицизму. Релігійного характеру братства набули саме під впливом боротьби з католицизмом та протестантизмом. Зрештою, вони стали на сторожі національних потреб, створюючи школи та друкарні. Братства ставлять перед собою завдання оберігати православну віру, тим самим рятувати українське населення від втрати своїх вірувань та переконань. Дослідники одностайно підкреслюють позитивну роль братств в очищенні релігійно-церковного життя, у розвитку освіти та культури.

Братські школи не давали вищої освіти, але давали досить пристойний рівень знань, якого вистачало людям для захисту себе від політики поневолення та захисту країни від занепаду; освіта мала гуманітарний характер. У школах при братствах обов'язково вивчали історію, математику, церковнослав'янську й українську мови. Також вивчали польську, грецьку латинську мови, поезію, риторику, діалектику, поетику, арифметику, геометрію, астрономію, музику. Найкращими на території Західної України вважалися Львівська та Луцька братські школи. Приділялась також увага засвоєнню культурної спадщини античної Європи, хоровому співу, малюванню, вивченню катехізису, богослов'я, згодом впровадили вивчення «семи вільних мистецтв» (Огієнко, 1992).

Поширення шкіл пробуджувало національну свідомість кожного українця, поширювало українські традиції та звичаї, популяризувало українську мову, сотні вихованців братських шкіл ста- вали викладачами, поширювали свої знання та розвивали вищу школу в Україні. Можна зробити висновок, що братські школи поставили розвиток освіти на сучасний і європейський рівень.

На початку XVII ст. вже існувала Острозька академія - перший вищий навчальний заклад на території України. Ї̈̈ заснував князь КостянтинВасиль Острозький на основі середньої школиколегії (1576р.), яку згодом почали називати «Академією». Костянтин-Василь Острозький у цьому закладі реалізував реформу шкільництва в дусі нової просвітньої програми та своїм меценатством довів, що й слов'янська мова може мати свою граматику та бути придатна до викладу вільних наук. Острозька академія стала зразком для багатьох українських шкіл; іï унікальність та оригінальність виявились у тому, що тут уперше поєдналися два типи культур: візантійська та західноєвропейська.

Початок діяльності академії характеризується значним інтелектуальним спалахом. Саме тоді простежується унікальна ознака Острозького культурно-освітнього центру (який, окрім академії, включав літературно-публіцистичний гурток та видавництво). Це залучення до співпраці діячів різних конфесій, ідеологічних, політичних орієнтацій.

На початку XVII ст. значна частина української молоді вчилася в католицьких школах. Щоб підняти рівень католицьких шкіл та взагалі католицтва, єпископат закликав до Польщі єзуїтів. Відтоді єзуїти починають засновувати школи також i на білорусько-українських землях.

20 січня 1661 р. король Ян II Казимир підписав диплом, який надавав єзуїтській колегії у Львові «гідність академії і титул університету» із правом викладання всіх тодішніх університетських дисциплін, присудження вчених ступенів бакалавра, ліценціата, магістра та доктора. Однак відразу ж після підписання диплому створення академії спричинило рішучу опозицію Краківського університету й окремих впливових осіб держави, що його підтримували. Незважаючи на перешкоди, у Львівському університеті навчання велося за зразком інших європейських академій. Усі університетські дисципліни викладали професори (Історія університету). На чолі університету стояв ректор.

Після розпуску в 1773 р. ордену єзуїтів Львівський університет було закрито. Однак незабаром низка підрозділів єзуїтської академії стали підвалинами Йосифінського університету у Львові.

16 листопада 1784 р. відновив свою діяльність Львівський університет. Деякий час у Львові на базі університету діяв ліцей. Це було пов'язано 3 
реформою вищої освіти в Австрійській державі (Історія університету).

На прохання львівського єпископа П. Білянського Йосип II тимчасово відкрив у 1787 р. при Львівському університеті так званий руський інститут - "Stadium ruthenum", куди могли б вступити українці без знання латинської мови (викладовою мовою там мала бути українська). Прийнято туди відразу 44 вихованців. Ректором "Stadium ruthenum" призначено А. Ангелловича, а в числі професорів були як галицькі українці, так і закарпатські - Петро Лодій та Іван Земанчик. Українське громадянство зустріло відкриття руського інституту з великим захопленням (Андрохович, 1922: 193).

На жаль, "Stadium ruthenum" не спричинив розбудження національного піднесення вихованців-українців. Сталося так із багатьох причин. Насамперед українська мова, якою викладалися деякі дисципліни, була мішаниною живої мови із церковнослов'янською, і ця «книжна» мова була тяжка для розуміння.

Значний вплив на розвиток Львівського університету мали події польського національновизвольного повстання 1830-1831 pp., особливо революції 1848 р., активну участь у яких брала студентська молодь. Під час листопадового повстання 1848 р. згорів університетський будинок, знищена його цінна наукова бібліотека, яка вже тоді налічувала понад 51 тис. томів. Згоріли цінні рукописи. Цілковито вийшло з ладу університетське обладнання, через що тривалий час не можна було розпочати заняття (Сірополко, 2001: $500)$.

Навчання в університеті для переважної частини студентів було платним. Безкоштовно навчалися студенти теологічного факультету. На світських факультетах такими пільгами користувалися лише частина студентів (які подавали свідоцтво про бідність і успішно складали семестрові колоквіуми). Крім плати за навчання, студенти сплачували таксу за імматрикуляцію (урочисте прийняття у студенти), платили за іспити, колоквіуми, семінарські заняття, за право користування бібліотекою тощо. Були і студентські стипендії, фонд яких складався в основному 3 пожертвувань приватних осіб. Студенти проживали в гуртожитках, проте кількість місць у них була обмеженою.

Висновки. Аналіз соціально-економічних та суспільно-політичних передумов виникнення класичної університетської освіти в Західній Україні в XVII - на поч. XX ст. дає підстави стверджувати, що становлення вищої освіти на цій території в цей період відбувалося в досить складних і нестабільних умовах.

Політична, національна, релігійна ситуація в Україні на початку XVII ст. зумовила існування двох напрямів освіти - православного та католицького. Велику роль у поширенні освіти (спочатку шкіл, а згодом вищої освіти) відіграли братства, які активно діяли вже на початку XVII ст.

Незважаючи на ці складні умови, початок XVII ст. прийнято вважати першим українським відродженням, оскільки цей час характеризується помітним розвитком освіти, друкарень та книжкової продукції.

Досягнення університетської освіти в Західній Україні в XVII - на поч. XX ст. дозволяють стверджувати, що система вітчизняної класичної університетської освіти має глибоке історичне коріння, грунтовну наукову основу й непересічну національну традицію.

За наявності значного наукового потенціалу ці університети традиційно були найбільшими центрами підготовки фахівців. Вони покликані забезпечувати кадрами різоманітних профілів науково-дослідні, політичні, культурні і правові інститути суспільства, адміністративні, що планують, директивні органи держави, промисловість, сільське господарство, медицину, органи освіти. Незважаючи на існування в умовах відсутності власної державності, ці навчальні заклади заклали фундамент для розбудови національної освіти в незалежній Україні.

Спираючись на досвід Львівського університету, можемо запропонувати створення при сучасних університетах навчальних установ або курсів для нацменшин. Тут би готували вчителя, який би міг навчатись мовою нацменшини, але 3 обов'язковим вивченням української мови й історії України.

\section{СПИСОК ВИКОРИСТАНИХ ДЖЕРЕЛ}

1. Андрохович А. Львівське "Stadium ruthenum". Записки Наукового m-ва ім. Шевченка у Львові. Львів, 1922. Т. CXXXII. С. 193-195.

2. Артемова Л. Історія педагогіки України : підручник. Київ : Либідь, 2006. 424 с.

3. Ефименко Г. Высшее образование в Украинской Советской Социалистической Республике. Киев : Высшая школа, $1983.94 \mathrm{c}$. 
4. Історія університету. URL: https://www.lnu.edu.ua/about/university-today-and-tomorrow/history/ (дата звернення: 20.12.2019).

5. Кугай К. Вплив братств на становлення та розвиток класичної університетської освіти в Західній Україні (XVII ст.). Науковий вісник Міжнародного гуманітарного університету. Серія «Історія. Філософія. Політологія» : збірник наукових праць. Одеса : Фенікс, 2019. Вип. № 16. С. 4-7.

6. Огієнко I. Українська культура: Коротка історія культурного життя українського народу. Київ, 1992. C. $140-142$.

7. Сірополко С. Історія освіти в Україні. Київ : Наукова думка, 2001. 912 с.

\section{REFERENCES}

1. Androkhovych A. Lvivske "Stadium ruthenium". Zapysky Naukovoho T-va im. Shevchenka u Lvovi [Lviv "Stadium ruthenum". Notes of the scientific community named after Shevchenko in Lviv]. Lviv, 1922. T. CXXXII. pp. $193-195$. [in Ukrainian].

2. Artemova L. V. Istoriia pedahohiky Ukrainy : pidruchnyk [History of pedagogics in Ukraine : textbook]. Kyiv : Lybid, 2006. 424 p. [in Ukrainian].

3. Efimenko G. G. Vyisshee obrazovanie v Ukrainskoy Sovetskoy Sotsialisticheskoy Respublike [Higher education in Ukrainian Soviet Socialist Republic]. Kyiv : Vyisshaya shkola, 1983. 94 p. [in Russian].

4. Istoriia universytetu. URL: https://www.lnu.edu.ua/about/university-today-and-tomorrow/history/ [in Ukrainian] (viewed on April 18, 2020).

5. Kugai K. B. Vplyv bratstv na stanovlennia ta rozvytok klasychnoi universytetskoi osvity v Zakhidnii Ukraini (XVII st.) [Brotherhoods influence on the formation and development of classical university education in Western Ukraine (XVII c.)]. Scientific bulletin of International humanitarian university. Edition : History. Philosophy. Politology. Odesa, 2019 . № 16. pp. 4-7 [in Ukrainian].

6. Ohiienko I. Ukrainska kultura: Korotka istoriia kulturnoho zhyttia ukrainskoho narodu [Ukrainian culture: Brief history of Ukrainian people cultural life] Kyiv, 1992. pp. 140-142 [in Ukrainian].

7. Siropolko S. Istoriia osvity v Ukraini [History of education in Ukraine]. Kyiv : Nauk. dumka, 2001.912 p. [in Ukrainian]. 